\title{
Effects of replacing fish meal with ensiled catfish (Pangasius hypophthalmus) by-products on the performance and carcass quality of finishing pigs*
}

\author{
N. Thi Thuy ${ }^{1}$, J.E. Lindberg ${ }^{2,3}$ and B. Ogle ${ }^{2}$ \\ ${ }^{1}$ College of Agriculture and Applied Biology, CanTho University \\ CanTho City, Vietnam \\ ${ }^{2}$ Department of Animal Nutrition and Management, Swedish University of Agricultural Sciences \\ P.O. Box 7024, S-750 07 Uppsala, Sweden
}

(Received 29 September 2010; revised version 14 February 2011; accepted 12 March 2011)

\begin{abstract}
Thirty castrated finishing male pigs were used to evaluate the effects of replacing fish meal (FM) with ensiled Tra catfish (Pangasius hypophthalmus) by-products (ECM) on performance and carcass quality. Pigs were allocated to individual pens and fed a control diet (ECM0) with FM as sole protein supplement, and experimental diets where 100 (ECM100), 75 (ECM75), 50 (ECM50) and $25 \%$ (ECM25) of the crude protein (CP) from FM was replaced by the CP from ECM. Feed intake was highest in ECM25 and lowest in ECM75 $(\mathrm{P}<0.05)$, and daily weight gain was higher in ECM100 than in the other treatments $(\mathrm{P}<0.01)$. Feed conversion ratio was improved $(\mathrm{P}<0.05)$ with higher inclusion of ECM in the diets. Carcass yield and dressing percentage were not affected $(\mathrm{P}>0.05)$ by treatment, but leaf fat and backfat thickness were higher and loin eye area lower in ECM100 compared with ECM0 $(\mathrm{P}<0.01)$. Ether extract and polyunsaturated fatty acid contents and meat colour values in Longissimus dorsi muscle increased $(\mathrm{P}<0.01)$ with ECM replacement level. Feed costs were lower in ECM100 and ECM75 compared with ECM25 and ECM0.
\end{abstract}

KEY WORDS: ensiled catfish by-products, tra catfish, finishing pig

\footnotetext{
* Supported by the Swedish International Development Cooperation Agency, Department for Research Cooperation (Sida-SAREC) through the regional MEKARN Project

${ }^{3}$ Corresponding author: e-mail: Jan-Erik.Lindberg@huv.slu.se
} 


\section{INTRODUCTION}

Pangasius hypophthalmus, fresh water Tra catfish, is the main commercially farmed fish in the Mekong Delta of Vietnam, and Tra catfish fillet is exported to many countries in the world (Lam et al., 2009). Tra catfish by-products (CBP), which include head, bone, skin, and the abdominal organs that remain after the two side fillets are removed are abundant. The CBP is ground fresh, boiled, and the oil removed, then dried to produce catfish by-product meal (CBM) in commercial catfish by-product processing companies. The CBM is included in livestock diets and exported to China, but the price is as high as that of marine fish meal. Although relatively inexpensive, it is not common for pig producers to use wet CBP in diets for pigs, because of problems of preservation, as the product deteriorates rapidly in tropical climates. Many studies have shown however that wet fish byproducts can become a valuable protein source in animal feeds if converted into silage. Ensiling the fresh by-products in combination with other locally available feeds rich in fermentable carbohydrates, such as sugar cane molasses, is a simple and appropriate method of conservation (Samuels et al., 1992; Kjos et al., 1999; Zahar et al., 2002). A study by Thuy et al. (2010) carried out in the Mekong Delta showed that catfish by-products can be successfully ensiled with $20-40 \%$ of sugar cane molasses and preserved for 1-2 months without affecting the quality.

Pig production is the dominant livestock enterprise in Vietnam, and pork production accounts for over $70 \%$ of the total meat production of the country, of which smallholders supply around $80 \%$ of the total (FAO, 2005). Under village conditions, production is mainly by small-scale farmers for income generation. The animals are fed using cheap local materials and unconventional feed resources rather than expensive high quality imported feeds. Feed represents approximately $65 \%$ of the production costs of market pigs, so decreasing the cost of feed is essential. Fermented liquid feed is inexpensive and is used to inhibit the growth of pathogenic bacteria such as $E$. coli in the feed and in the gastrointestinal tract of piglets, and to increase lactic acid bacteria in the stomach of growing pigs (Canibe and Jensen, 2003). Fermented liquid feed is characterized by low $\mathrm{pH}$, high concentration of organic acids, especially lactic acid, and can improve the digestibility of some dietary components (Hong and Lindberg, 2007). This study was conducted to evaluate the effects of replacing fish meal with ensiled catfish by-products on growing pig performance, carcass quality and economic benefits. 


\section{MATERIAL AND METHODS}

\section{Animals and experimental design}

A total of 30 crossbreed castrated (Yorkshire $x$ Landrace) male pigs with an initial average liveweight of $45.0 \pm 3.1 \mathrm{~kg}($ mean $\pm \mathrm{SD})$ was used in the experiment. Before starting the experiment, the pigs were given the same commercial feed until $35 \mathrm{~kg}$ liveweight, and then were given the experimental feeds for 2 weeks of adaptation. All pigs were vaccinated against hog cholera and foot and mouth disease, and were allocated into six groups of five, balanced for initial body weight, and were housed in 30 individual $60 \times 150 \mathrm{~cm}$ pens, each with a feeder and an automatic nipple drinker. The daytime temperature during the experiment ranged from 30 to $33^{\circ} \mathrm{C}$. The experimental feed was given ad libitum twice per day at 9.00 and $15.00 \mathrm{~h}$, and refusals were collected the following morning before the first meal, and samples stored in a freezer for dry matter (DM) analysis. The experiment lasted ten weeks and the pigs were weighed every two weeks. Feed intake was recorded, and then feed conversion ratio (FCR) was calculated as feed intake divided by weight gain.

\section{Diets and feeding}

The study was conducted according to a randomized complete block design with 5 treatments and 6 replications. Before the experiment started, samples of feed ingredients were taken for analysis of DM and chemical composition. Metabolizable energy (ME) values of the feed ingredients were calculated according to tables of the Chemical Composition of Animal Feed in Vietnam (Chinh et al., 1995). Five experimental diets were introduced to the pigs, and were formulated to contain 13.3 to $13.4 \%$ crude protein (CP), and 13.0 to 13.1 $\mathrm{MJ} / \mathrm{kg}$ of ME. Rice bran, broken rice and maize meal were the basal ingredients, with fish meal (FM) as the sole protein supplement, and 4 experimental diets were formulated in which $100,75,50$ and $25 \%$, respectively, of the CP from FM was replaced by the $\mathrm{CP}$ from ensiled catfish by-product (ECM). All diets were supplemented with a standard mixture of vitamins and minerals.

Fish meal was bought from factories that specifically process small marine fish. The boiled, ground catfish by-product was purchased once per week at a catfish by-product meal factory near to the experimental farm, and then mixed with sugar cane molasses (M) of 71 degree Brix (wet weight basis) in a ratio of 8:2 (CBP: M). The mixture was placed in plastic bags and sealed to prevent air contamination and then ensiled. The ensiled product (ECM) was made every week and then stored at room temperature $\left(29\right.$ to $\left.31^{\circ} \mathrm{C}\right)$ for one month before mixing daily with the basal ingredients. 


\section{Carcass measurements}

After the ten weeks of the feeding trial, all pigs were transported to a local abattoir over a period of 3 days (10 pigs/day). The pigs were slaughtered after $12 \mathrm{~h}$ of starvation; they were stunned, exsanguinated and eviscerated. The hot carcass weight was the weight after slaughter, but excluding blood, hair, visceral organs and gastrointestinal tract. Dressed weight was the hot carcass weight minus head, lower legs, tail and leaf fat, and dressing percentage was calculated. All the parameters were measured on the left side of each carcass, including backfat thickness at the $10^{\text {th }}$ rib, three-quarters of the lateral length of the Longissimus dorsi (LD) muscle perpendicular to the outer skin surface, and at three other points at the $1^{\text {st }}$ rib, last rib and last lumber vertebra using a ruler, and the average backfat thickness was calculated. The loin eye area was measured by tracing the LD muscle surface area at the $10^{\text {th }}$ rib on acetate paper, and by using a compensating planimeter at slaughter. Finally, fresh loin muscle samples were taken at the $10^{\text {th }}$ rib and transported to the laboratory for $\mathrm{pH}$ measurement, chemical analysis of $\mathrm{DM}, \mathrm{CP}$, ether extract (EE), and ash, colour value and fatty acid content.

\section{Chemical analysis}

The $\mathrm{pH}$ of the meat was measured at $24 \mathrm{~h}$ post-mortem using a digital $\mathrm{pH}$ meter. Approximately $10 \mathrm{~g}$ samples were ground into small pieces and $90 \mathrm{ml}$ of distilled water was added. Slurry was then made using a homogenizer and the $\mathrm{pH}$ was recorded after the $\mathrm{pH}$ meter had been calibrated with standard buffers of $\mathrm{pH}$ 4.0 and 7.0 at room temperature. The chemical composition of feed ingredients, diets and meat was determined using the following standard AOAC (1990) methods. Dry matter of ECM, diets, feed refusals and meat was determined by drying the fresh samples at $105^{\circ} \mathrm{C}$ until dry. Crude protein was determined by the Kjeldahl method. Total ash was the residue after ashing the sample at $550^{\circ} \mathrm{C}$ and organic matter $(\mathrm{OM})$ was calculated by difference. Ether extract was determined by Soxhlet extraction. Fatty acid composition of loin muscle samples from the $10^{\text {th }}$ rib was analysed by gas chromatography (GC), and total lipid content of muscle was following the chloroform-methanol extraction procedure of Folch et al. (1957). Extracted lipids were converted to fatty acid methyl ester using $\mathrm{BF}_{3}$ and methanolic KOH, and analysed by GC (HP5890, Hewlett-Packard, FID- ISO 5509). The objective meat colour on the LD was evaluated on the $10^{\text {th }}-11^{\text {st }}$ rib surface using a colorimeter (Chromameter Minolta, CR- 200, Japan), and expressed as Hunter $L^{*}, a^{*}, b^{*}$ values of objective colour. The $L^{*}$ reading is a measure of the lightness or darkness of a meat sample, the $\mathrm{a}^{*}$ reading is a measure of the redness or greenness of the sample (the more positive the number, the redder the sample), while the $b^{*}$ reading is a measure of yellowness and blueness (the more positive the number, the yellower the sample). 


\section{Statistical analysis}

Analysis of variance was performed according to a randomized block design, using the General Linear Model of Minitab Statistical Software Version 15. Leaf fat, backfat thickness and loin eye area were corrected by covariance for differences in carcass weight. Tukey pair - wise comparisons were used to determine differences between treatment means at $\mathrm{P}<0.05$.

\section{RESULTS}

\section{Chemical composition of the diets}

The chemical composition and metabolizable energy content of the raw materials used to compose the experimental diets are presented in Table 1.

Table 1. Dry matter (\%), chemical composition ${ }^{1}(\%$ of DM) and metabolizable energy contents $(\mathrm{MJ} / \mathrm{kg} \mathrm{DM})$ of ingredients in the experimental diets

\begin{tabular}{lcccccccc}
\hline Ingredient & DM & CP & EE & Ash & CF & NFE & OM & ME \\
\hline Rice bran & 81.2 & 9.8 & 9.5 & 7.6 & 10.2 & 62.9 & 92.4 & 11.4 \\
Maize meal & 86.7 & 8.1 & 0.7 & 3.3 & 3.6 & 84.3 & 96.7 & 14.2 \\
Broken rice & 87.5 & 7.0 & 0.6 & 3.8 & 7.0 & 81.6 & 96.2 & 14.1 \\
Sugar cane molasses (M) & 71.0 & 3.4 & - & 12.3 & - & - & 87.7 & 13.1 \\
Catfish by-product (CBP) & 43.5 & 37.7 & 19.4 & 33.0 & 2.1 & 7.8 & 67.0 & 12.8 \\
Fish meal & 90.1 & 51.5 & 8.3 & 30.4 & 3.2 & 6.6 & 69.6 & 11.9 \\
ECM $^{2}$ & 48.5 & 30.5 & 14.3 & 22.1 & 2.1 & 31.0 & 77.9 & 12.9 \\
\hline
\end{tabular}

${ }^{1}$ DM - dry matter; CP - crude protein; EE - ether extract; CF - crude fibre; NFE - N-free extractives; $\mathrm{OM}$ - organic matter; ME - metabolizable energy; ${ }^{2}$ catfish by-product ensiled with sugar cane molasses at a ratio of $8: 2(\mathrm{CBP}: \mathrm{M})$

The DM, CP and EE contents of fish meal (90.1, 51.5 and 8.3\%, respectively) were different to those of the catfish by-products $(43.5,37.7$ and $19.4 \%$, respectively), which was the material used to make silage with sugar cane molasses, so as a result the ensiled catfish by-product was low in DM and CP (48.5 and 30.5\%, respectively) but high in EE (14.3\%) content. The chemical composition of the experimental diets is presented in Table 2, and the DM of the diets decreased with increasing inclusion of ECM, from $85.7 \%$ in ECM0 to $76.6 \%$ in ECM100. All experimental diets had the same contents of CP (13.3-13.4\%) and calculated ME (13.0-13.1 MJ/kg). Ether extract and ash contents increased with increasing inclusion of ECM, from 3.9 and $7.9 \%$ in ECM0 to 6.5 and $8.9 \%$ in ECM100, respectively. 
Table 2. Ingredient ( $\%$ of DM), chemical composition (\% of DM), energy content (MJ/kg feed) and cost (VND/kg DM) of the experimental diets

\begin{tabular}{|c|c|c|c|c|c|}
\hline \multirow{2}{*}{ Item } & \multicolumn{5}{|c|}{ Diet $^{1}$} \\
\hline & ECM0 & ECM25 & ECM50 & ECM75 & ECM100 \\
\hline \multicolumn{6}{|l|}{ Ingredients } \\
\hline broken rice & 29.1 & 25.0 & 23.1 & 22.0 & 18.3 \\
\hline rice bran & 26.7 & 30.6 & 33.0 & 32.0 & 33.0 \\
\hline maize meal & 32.0 & 30.0 & 27.5 & 27.0 & 27.0 \\
\hline fish meal & 12.0 & 9.0 & 6.0 & 3.0 & 0 \\
\hline $\begin{array}{l}\text { ensiled catfish by- } \\
\text { products(ECM) }\end{array}$ & 0 & 5.2 & 10.2 & 15.8 & 21.5 \\
\hline vitamin-mineral premix ${ }^{2}$ & 0.2 & 0.2 & 0.2 & 0.2 & 0.2 \\
\hline \multicolumn{6}{|l|}{ Chemical composition } \\
\hline dry matter & 85.7 & 83.4 & 81.2 & 79.0 & 76.6 \\
\hline organic matter & 92.1 & 91.8 & 91.6 & 91.4 & 91.1 \\
\hline crude protein & 13.4 & 13.4 & 13.3 & 13.3 & 13.3 \\
\hline ether extract & 3.9 & 4.8 & 5.4 & 5.9 & 6.5 \\
\hline ash & 7.9 & 8.2 & 8.7 & 8.6 & 8.9 \\
\hline crude fibre & 6.3 & 6.3 & 6.4 & 6.2 & 6.1 \\
\hline $\mathrm{N}$-free extractives & 68.3 & 67.1 & 66.3 & 65.9 & 65.1 \\
\hline Metabolizable energy & 13.1 & 13.0 & 13.0 & 13.0 & 13.0 \\
\hline Cost & 6893 & 6569 & 6290 & 6082 & 5815 \\
\hline
\end{tabular}

${ }^{1}$ ECM0: $100 \%$ crude protein (CP) from fish meal (FM); ECM25 - 75\% CP from FM and 25\% CP from ensiled catfish by-products (ECM); ECM50 - 50\% CP from FM and 50\% CP from ECM; ECM75 - 25\% CP from FM and 75\% from ECM; ECB100: 100\% CP from ECM

${ }^{2}$ per kg complete diet: IU: A $48 \times 10^{5}$, vit. D $48 \times 10^{4}$, vit. E $44 \times 10^{2}$; mg: vit. $\mathrm{K}_{3} 280$, vit. $\mathrm{B}_{1} 600$, vit. $\mathrm{B}_{2} 200$, vit. $\mathrm{B}_{6} 320$, folic acid 160 , nicotinic acid $44 \times 10^{2}$, pantothenic acid $24 \times 10^{2}$; mcg: vit. $\mathrm{B}_{12} 6 \times 10^{3}$, biotin $10^{4}$; minerals: mg: Fe $475 \times 10^{2}, \mathrm{Cu} 315 \times 10^{2}, \mathrm{Zn} 475 \times 10^{2}$, I 350, Co 47, Mn $195 \times 10^{2}$, Se 39

\section{Growth performance and economic efficiency}

The experiment was carried out without any health problems. The effect of ensiled catfish by-product on pig performance is shown in Table 3. There was significantly higher $(\mathrm{P}<0.01)$ final body weight in pigs fed ECM50 $(95.7 \mathrm{~kg})$, ECM75 $(96.0 \mathrm{~kg})$ and ECM100 $(98.0 \mathrm{~kg})$ compared with ECM25 $(93.0 \mathrm{~kg})$ and ECM0 $(93.2 \mathrm{~kg})$. The highest average daily gain (ADG) was in ECM100 (760 $\mathrm{g} /$ day), the lowest in ECM0 (683 g/day) and ECM25 (686 g/day). Decreasing average daily feed intake (ADFI) $(\mathrm{P}<0.05)$ was found with increasing inclusion of ECM. The highest ADFI was in ECM0 (2.47 kg DM/day) and ECM25 (2.48 $\mathrm{kg} \mathrm{DM} /$ day), and the lowest in ECM75 (2.35 kg DM/day). Feed conversion ratio (FCR) was highest in ECM0 (3.62 kg feed DM/kg gain) and lowest in ECM100 $(3.15 \mathrm{~kg}$ feed $\mathrm{DM} / \mathrm{kg}$ gain) $(\mathrm{P}<0.05)$. The cost of feed per $\mathrm{kg}$ gain decreased with increasing inclusion of ECM in the diet, and in ECM25, ECM50, ECM75 and ECM100 was 96, 83, 79 and 72\%, respectively, compared with ECM0. 
Table 3. Effects of ensiled catfish by-products on the growth performance of finishing pigs

\begin{tabular}{|c|c|c|c|c|c|c|c|}
\hline \multirow{2}{*}{ Item } & \multicolumn{5}{|c|}{ Diet $^{1}$} & \multirow[b]{2}{*}{$\mathrm{SE}$} & \multirow[b]{2}{*}{$\mathrm{P}$} \\
\hline & ECM0 & ECM25 & ECM50 & ECM75 & ECM100 & & \\
\hline Initial liveweight, $\mathrm{kg}$ & 45.3 & 45.0 & 44.8 & 45.1 & 44.8 & 0.23 & 0.56 \\
\hline Final liveweight, kg & $93.2^{\mathrm{b}}$ & $93.0^{\mathrm{b}}$ & $95.7^{\mathrm{ab}}$ & $96^{\mathrm{ab}}$ & $98.0^{\mathrm{a}}$ & 0.95 & 0.001 \\
\hline Duration, days & 70 & 70 & 70 & 70 & 70 & & \\
\hline Liveweight gain, g/day & $683^{b}$ & $686^{\mathrm{b}}$ & $727^{\mathrm{ab}}$ & $727^{\mathrm{ab}}$ & $760^{\mathrm{a}}$ & 10.7 & 0.001 \\
\hline ADFI, kg DM/day ${ }^{2}$ & $2.47^{\mathrm{ab}}$ & $2.48^{\mathrm{a}}$ & $2.40^{\mathrm{ab}}$ & $2.35^{\mathrm{b}}$ & $2.39^{\mathrm{ab}}$ & 0.03 & 0.02 \\
\hline FCR, $\mathrm{kg}$ feed $/ \mathrm{kg}$ gain ${ }^{2}$ & $3.62^{\mathrm{a}}$ & $3.62^{\mathrm{a}}$ & $3.30^{\mathrm{ab}}$ & $3.23^{\mathrm{ab}}$ & $3.15^{\mathrm{b}}$ & 0.08 & 0.001 \\
\hline Cost/kg gain, thousand VND & $24.9^{\mathrm{a}}$ & $23.9^{\mathrm{a}}$ & $20.9^{\mathrm{b}}$ & $19.6^{\mathrm{b}}$ & $18.3^{\mathrm{b}}$ & 0.65 & 0.001 \\
\hline Cost/gain comparison, $\%$ & 100 & 96 & 83 & 79 & 72 & & \\
\hline
\end{tabular}

${ }^{1}$ explanation see Table $2 ;{ }^{2}$ ADFI - average daily feed intake; FCR - feed conversion ratio

$\mathrm{a,b}$ within rows, values with different superscript letters are different $(\mathrm{P}<0.05)$

\section{Carcass characteristics and meat quality}

The carcass traits, backfat thickness and loin eye area are presented in Table 4. There was no significant difference in carcass yield and dressing percentage among diets, but leaf fat and backfat thickness increased $(\mathrm{P}<0.05)$ when pigs were fed higher levels of ECM. The highest leaf fat was $1.47 \mathrm{~kg}$ (ECM100) and $1.42 \mathrm{~kg}$ (ECM75) and lowest $1.22 \mathrm{~kg}$ (ECM0) and $1.24 \mathrm{~kg}$ (ECM25). The backfat thickness at the $10^{\text {th }}$ rib and average backfat thickness were highest in ECM100 (2.24 and $2.38 \mathrm{~cm}$, respectively) and lowest in ECM0 (2.07 and 2.14 $\mathrm{cm}$, respectively). Loin eye area was lowest in ECM100 $\left(39.5 \mathrm{~cm}^{2}\right)$ and ECM75 $\left(40.2 \mathrm{~cm}^{2}\right)$ and highest in ECM0 $\left(42.5 \mathrm{~cm}^{2}\right)$ and ECM25 $\left(42.2 \mathrm{~cm}^{2}\right)$.

Table 4. Effect of ensiled catfish by-products on carcass characteristics of finishing pigs

\begin{tabular}{|c|c|c|c|c|c|c|c|}
\hline \multirow{2}{*}{ Item } & \multicolumn{5}{|c|}{ Diet $^{1}$} & \multirow{2}{*}{ SE } & \multirow{2}{*}{$\mathrm{P}$} \\
\hline & ECM0 & ECM25 & ECM50 & ECM75 & ECM100 & & \\
\hline Slaughter weight, $\mathrm{kg}$ & 93.9 & 93.8 & 96.5 & 96.5 & 98.8 & & \\
\hline Hot carcass weight, $\mathrm{kg}$ & 70.9 & 71.3 & 73.3 & 74.0 & 75.7 & & \\
\hline Carcass yield, \% & 75.5 & 76.0 & 75.9 & 76.6 & 76.7 & 0.31 & 0.08 \\
\hline Dressing percentage, $\%$ & 71.0 & 71.2 & 71.6 & 72.1 & 72.2 & 0.35 & 0.10 \\
\hline Leaf fat, $\mathrm{kg}$ & $1.22^{\mathrm{b}}$ & $1.24^{\mathrm{b}}$ & $1.34^{\mathrm{ab}}$ & $1.42^{\mathrm{a}}$ & $1.47^{\mathrm{a}}$ & 0.03 & 0.001 \\
\hline \multicolumn{8}{|l|}{ Backfat thickness, $\mathrm{cm}$} \\
\hline at $10^{\text {th }}$ rib & $2.07^{\mathrm{b}}$ & $2.14^{\mathrm{ab}}$ & $2.19^{\mathrm{a}}$ & $2.14^{\mathrm{ab}}$ & $2.24^{\mathrm{a}}$ & 0.02 & 0.001 \\
\hline average backfat thickness & $2.14^{\mathrm{c}}$ & $2.23^{\mathrm{b}}$ & $2.26^{\mathrm{b}}$ & $2.31^{\mathrm{ab}}$ & $2.38^{\mathrm{a}}$ & 0.02 & 0.001 \\
\hline Loin eye area, $\mathrm{cm}^{2}$ & $42.5^{\mathrm{a}}$ & $42.2^{\mathrm{a}}$ & $41.4^{\mathrm{ab}}$ & $40.2^{\mathrm{bc}}$ & $39.5^{\mathrm{c}}$ & 0.40 & 0.001 \\
\hline
\end{tabular}

${ }^{1}$ explanation see Table 2

a,b,c within rows, values with different superscript letters are different $(\mathrm{P}<0.05)$

The chemical composition and colour of the longissimus dorsi (LD) muscle is shown in Table 5. There was no significant difference in DM, CP and ash contents of LD muscle, but the EE content in the LD muscle of pigs fed ECM100 (5.24\%) was higher than in ECM0 (4.62\%) and ECM25 (4.65\%). The meat colour values 
Table 5. Effects of ensiled catfish by-products on the chemical composition and colour of Longisimus dorsi (LD) muscle in finishing pigs

\begin{tabular}{|c|c|c|c|c|c|c|c|}
\hline \multirow{2}{*}{ Item } & \multicolumn{5}{|c|}{ Diet $^{1}$} & \multirow[b]{2}{*}{ SE } & \multirow{2}{*}{$\mathrm{P}$} \\
\hline & ECM0 & ECM25 & ECM50 & ECM75 & ECM100 & & \\
\hline \multicolumn{8}{|c|}{ Chemical composition, \% } \\
\hline moisture & 73.9 & 73.5 & 73.8 & 74.1 & 74.1 & 0.15 & 0.06 \\
\hline crude protein & 21.0 & 20.9 & 21.3 & 21.4 & 20.8 & 0.11 & 0.18 \\
\hline ether extract & $4.62^{\mathrm{b}}$ & $4.65^{\mathrm{b}}$ & $5.06^{\mathrm{a}}$ & $5.22^{\mathrm{a}}$ & $5.24^{\mathrm{a}}$ & 0.08 & 0.001 \\
\hline ash & 1.11 & 1.07 & 1.11 & 1.09 & 1.10 & 0.01 & 0.09 \\
\hline $\mathrm{pH}$ & 5.5 & 5.5 & 5.6 & 5.6 & 5.6 & 0.03 & 0.06 \\
\hline \multicolumn{8}{|l|}{ Colour of LD muscle } \\
\hline lightness, $L^{* 2}$ & $40.8^{\mathrm{b}}$ & $40.9^{b}$ & $41.6^{\mathrm{ab}}$ & $42.3^{\mathrm{a}}$ & $42.2^{\mathrm{a}}$ & 0.19 & 0.001 \\
\hline redness, $a^{* 2}$ & $7.26^{\mathrm{d}}$ & $7.26^{\mathrm{d}}$ & $7.97^{\mathrm{c}}$ & $8.33^{\mathrm{b}}$ & $9.09^{\mathrm{a}}$ & 0.08 & 0.001 \\
\hline yellowness, $b^{* 2}$ & $5.18^{\mathrm{bc}}$ & $5.04^{\mathrm{c}}$ & $5.40^{\mathrm{bc}}$ & $5.53^{\mathrm{b}}$ & $6.07^{\mathrm{a}}$ & 0.09 & 0.001 \\
\hline
\end{tabular}

of the LD muscle increased with increasing inclusion of ECM. The L* values increased from 40.8 in ECM0 to 42.3 in ECM75 and 42.2 in ECM100. Similarly, the $\mathrm{a}^{*}$ value of ECM100 (9.09) was higher than in ECM0 (7.26). However, the $b^{*}$ values were highest in pigs fed ECM100 (6.07) and ECM75 (5.53) and lowest in pigs fed ECM25 (5.04).

Table 6. Effect of ensiled catfish by-products on fatty acid composition of Longisimus dorsi (LD) muscle in finishing pigs, $\%$ of total fatty acids

\begin{tabular}{|c|c|c|c|c|c|c|c|}
\hline \multirow{2}{*}{ Fatty acid } & \multicolumn{5}{|c|}{ Diet $^{1}$} & \multirow{2}{*}{ SE } & \multirow{2}{*}{$\mathrm{P}$} \\
\hline & ECM0 & ECM25 & ECM50 & ECM75 & ECM100 & & \\
\hline$\overline{\mathrm{C} 12: 0}$ & 0.13 & 0.13 & 0.13 & 0.12 & 0.12 & 0.00 & 0.69 \\
\hline $\mathrm{C} 14: 0$ & 1.60 & 1.57 & 1.66 & 1.62 & 1.58 & 0.03 & 0.14 \\
\hline C16:0 & 28.2 & 27.6 & 27.4 & 27.1 & 27.5 & 0.27 & 0.10 \\
\hline C18:0 & 13.3 & 13.5 & 13.4 & 13.8 & 13.6 & 0.12 & 0.11 \\
\hline $\mathrm{C} 16: 1, \mathrm{n}-9$ & 3.51 & 3.57 & 3.53 & 3.56 & 3.52 & 0.03 & 0.53 \\
\hline $\mathrm{C} 18: 1, \mathrm{n}-9$ & 33.1 & 32.7 & 33.1 & 32.6 & 33.0 & 0.26 & 0.41 \\
\hline C20:1 & $0.62^{\mathrm{b}}$ & $0.65^{\mathrm{ab}}$ & $0.68^{\mathrm{ab}}$ & $0.69^{\mathrm{a}}$ & $0.70^{\mathrm{a}}$ & 0.01 & 0.001 \\
\hline $\mathrm{C} 18: 2, \mathrm{n}-6$ & $12.0^{\mathrm{b}}$ & $12.4^{\mathrm{ab}}$ & $12.6^{\mathrm{ab}}$ & $12.8^{\mathrm{a}}$ & $12.9^{\mathrm{a}}$ & 0.15 & 0.001 \\
\hline $\mathrm{C} 18: 3, \mathrm{n}-3$ & $2.37^{\mathrm{c}}$ & $2.42^{\mathrm{b}}$ & $2.44^{\mathrm{b}}$ & $2.48^{\mathrm{a}}$ & $2.51^{\mathrm{a}}$ & 0.01 & 0.001 \\
\hline $\mathrm{C} 20: 4, \mathrm{n}-6$ & 0.36 & 0.36 & 0.39 & 0.36 & 0.38 & 0.01 & 0.12 \\
\hline C20:5, n-3 EPA & 0.76 & 0.77 & 0.76 & 0.76 & 0.77 & 0.00 & 0.85 \\
\hline $\mathrm{C} 20: 2, \mathrm{n}-6$ & $0.51^{\mathrm{a}}$ & $0.51^{\mathrm{a}}$ & $0.49^{\mathrm{ab}}$ & $0.44^{\mathrm{c}}$ & $0.46^{\mathrm{bc}}$ & 0.01 & 0.001 \\
\hline C22:5, n-3 DPA & $0.91^{b}$ & $0.92^{\mathrm{b}}$ & $0.97^{\mathrm{a}}$ & $0.97^{\mathrm{a}}$ & $0.97^{\mathrm{a}}$ & 0.01 & 0.001 \\
\hline C22:6, n-3 DHA & $1.23^{\mathrm{b}}$ & $1.21^{\mathrm{b}}$ & $1.32^{\mathrm{a}}$ & $1.33^{\mathrm{a}}$ & $1.33^{\mathrm{a}}$ & 0.00 & 0.01 \\
\hline SFA $^{2}$ & 43.3 & 42.8 & 42.6 & 42.7 & 42.8 & 0.31 & 0.59 \\
\hline MUFA $^{2}$ & 37.2 & 36.9 & 37.3 & 36.8 & 37.2 & 0.37 & 0.61 \\
\hline PUFA $^{2}$ & $18.2^{\mathrm{c}}$ & $18.6^{\mathrm{bc}}$ & $18.9^{\mathrm{ab}}$ & $19.1^{\mathrm{ab}}$ & $19.3^{\mathrm{a}}$ & 0.15 & 0.00 \\
\hline PUFA/SFA & $0.42^{\mathrm{b}}$ & $0.43^{\mathrm{ab}}$ & $0.44^{\mathrm{a}}$ & $0.45^{\mathrm{a}}$ & $0.45^{\mathrm{a}}$ & 0.00 & 0.00 \\
\hline
\end{tabular}


Fatty acid composition of Longissimus dorsi (LD) muscle

There was no significant difference among diets $(\mathrm{P}>0.05)$ in saturated (SFA) and monounsaturated fatty acids (MUFA) in the LD muscle (Table 6). However, polyunsaturated fatty acids (PUFA), such as linoleic (C18:2, n-6), $\alpha$-linolenic (C18:3, n-3), C22:5, n-3 (DPA) and C22:6, n-3 (DHA), increased with higher inclusion of ECM in the diet, with the highest total PUFA in ECM100 (19.3\%) and lowest value in ECM0 $(18.2 \%)(\mathrm{P}<0.05)$.

\section{DISCUSSION}

Tra catfish by-product composition varies according to by-product input material and the procedure for fat extraction, and the CBP input material, which was mainly head and bone by-products, had lower CP and DM contents than in fish meal. The study of Thuy et al. (2010) showed that CBP can be successfully ensiled with 20 to $40 \%$ of sugar cane molasses, and can be kept for around 2 months without affecting quality, and this was confirmed in the present study. Ensiling involved boiling and grinding the catfish by-product and adding sugar cane molasses to get the $\mathrm{pH}$ below 4.5, at which growth of spoilage bacteria is prevented. The increasing DM and decreasing CP contents in ECM compared with the CBP were due to the inclusion of sugar cane molasses ( $20 \%$ in wet weight) which is higher in DM and lower in CP content than CBP. The higher the ECM replacement the higher crude fat contents in the diet, which can be explained by the higher EE in CBP than in the fish meal used, which was produced from small, whole marine fish. Moreover, all diets were formulated to contain similar $\mathrm{CP}$ and ME to avoid the effect of different levels of nitrogen and energy. Hsia and $\mathrm{Lu}$ (2004) showed that under moderately high environmental temperatures (around $30^{\circ} \mathrm{C}$ ), the weight gain of pigs increased with increasing dietary protein and energy contents.

The inclusion of ECM in the diets slightly reduced the average daily feed intake (ADFI), probably due to differences in palatability. In an earlier study with ensiled catfish by-product, after 4 weeks of ensiling the concentration of acetic acid (21\% of total organic acids) was high (Thuy et al., 2010) and Brooks et al. (2001) showed that a high level of acetic acid in fermented liquid feed is undesirable because it can reduce the palatability. In addition the high fat content of the diets with high inclusion levels of ECM could have reduced feed intake, as Michael (2001) showed that daily intake of diets with high levels of fat was reduced. 
Although there was a small but significant decrease in intake of the high ECM diets, average daily gain (ADG) of pigs fed ECM100 were 11\% higher than in ECM0. This can be explained by the higher fat content in ECM100, which mainly came from catfish oil, which has been shown to improve the efficiency of energy utilization in pigs maintained at high ambient temperatures (Stahly, 1984). This is in agreement with previous research from Green et al. (1988), who found that animals fed on oily fish silage grew significantly faster than those given no fish silage, and increasing the level of oily fish silage in the diet also resulted in an improvement in feed conversion ratio. Similarly, Øverland et al. (1999) showed that a high fat diet (10\% added fat) gave a significantly higher ADG, lower total feed intake and better feed efficiency compared with a low fat diet $(1.5 \%$ added fat) and in constant ME content diets. In addition, fish silage is considered to be an excellent protein source, with a high biological value (Vidotti et al., 2003), because during silage processing, proteins are hydrolysed to free amino acids, thus increasing their availability for protein biosynthesis. Moreover, the studies of Urlings et al. (1993), Jensen and Mikkelsen (1998) and Scholten et al. (1999) showed that fermented feed resulted in improved growth performance and reduced mortality and mobility in growing-finishing pigs because of enhanced nutrient availability and reduced growth and shedding of pathogenic bacteria due to the low $\mathrm{pH}$, which is a result of the high concentration of organic acids (Van Winsen et al., 2001). Similarly results from Lallo et al. (1997) showed that poultry offal ensiled with sugar cane molasses can replace up to $30 \%$ of commercial feeds for growing pigs without affecting growth performance and health.

Feed conversion ratio (FCR) of pigs fed the high ECM diets was improved as a result of lower feed intake and higher growth rate. An additional reason for the lower FCR could be that the catfish by-product was heated before ensiling, which could have improved diet digestibility, as was confirmed by Urlings et al. (1993), who found that mild heating applied before the fermentation of poultry by-products probably contributed to the better growth and the reduced FCR in pigs.

The supplementation of catfish by-product silage did not affect hot carcass and dressing percentage. Kjos et al. (1999) reported that the inclusion of defatted fish silage at the level of $50 \mathrm{~g} / \mathrm{kg}$ diet, corresponding to $9 \%$ of the total protein, had no negative effects on the dressing percentage or sensory quality of pig meat. In the present study, backfat thickness and EE contents in LD increased with higher ECM inclusion in the diet, which was also found by Stahly and Cromwell (1979) who showed that dietary fat supplementation increased carcass backfat thickness in pigs raised at high ambient temperatures. Urlings et al. (1993) also showed that feeding pigs with fermented poultry by-product which was heated before fermentation also increased backfat thickness, and Kim et al. (2006) reported that 
addition of fermented persimmon shell to the diet increased the EE content of the LD muscle.

Chemical analysis of LD indicated that there were no differences in moisture, CP and ash, among diets, but the meat from pigs fed ECM100 and ECM75 had higher $\mathrm{a}^{*}$ and $\mathrm{b}^{*}$ values than those given ECM0 and ECM25.The cause of the higher $\mathrm{a}^{*}$ and $\mathrm{b}^{*}$ values could probably be linked to the higher concentration of C16:0 and C18:0 in the LD fat, which makes the lipid less translucent and therefore brightens the colour of the pork (Teye et al., 2006). Also the lower $\mathrm{pH}$ in ECM0 is an indicator of lower colour value in LD, because the lower the $\mathrm{pH}$ the paler the meat colour. Moreover, Kouba (2006) reported that a high degree of tissue unsaturation can result in darker meat colour, because tissue unsaturation can cause a more rapid conversion of the red muscle pigment myoglobin to brown metmyoglobin.

Fat and fatty acids are important because of their effects on human health, and fatty acid composition is a major factor in the nutritional value of meat. A ratio of polyunsaturated fatty acids to saturated fatty acids of 0.4 or above is considered suitable for human consumption (Department of Health, 1994). The pig is unable to synthesize essential fatty acids such as linoleic and linolenic acid, and they must be supplied in the diet, and the fatty acid composition of pig meat is mostly controlled by diet (Kristinsson et al., 2001). The fat in ECM is mainly from catfish oil which is a rich source of essential polyunsaturated fatty acids in both the omega- 3 and omega-6 families. Ho and Paul (2009) showed that the high absolute contents of DHA (C22:6, n-3) and EPA (C20:5, n-3) in Tra catfish makes it a potentially valuable source of omega-3 fatty acids. Linoleic acid (8.4\%) is the major PUFA in Tra catfish, followed by DHA (4.7\%). Thus, the higher the inclusion rate of ECM in the diet, the higher the DHA, EPA, DPA and other polyunsaturated fatty acids in LD. This is in agreement with Lauridsen et al. (1999), Bryhni et al. (2002) and Hallenstvedt et al. (2010), who showed that feeding fish oil to pigs did not affect the sensory quality of loin, but increased the level of DHA, EPA and DPA in muscle. Although fish meal normally contains high levels of PUFA (Jonsdottir et al., 2003), the fish meal used in the present experiment was made from small marine fish which had a lower PUFA content than in catfish by-product silage.

The feed costs per kg liveweight gain were much lower in ECM100 and ECM75 (18,300 and 19,600 VND/kg gain, respectively) compared with ECM25 and ECM0 (23,900 and 24,900 VND/kg gain, respectively). So, $100 \%$ replacement of fish meal by ensiled catfish by-product reduced feed cost per $\mathrm{kg}$ gain to around 72 of the $100 \%$ fish meal diet. 


\section{CONCLUSIONS}

Replacing fish meal by ensiled catfish by-product improved the performance and meat quality of finishing pigs, but resulted in an increase in backfat thickness. However, because of the reduced feed costs, complete replacement of fish meal would still be profitable for pig producers in the Mekong Delta.

\section{REFERENCES}

AOAC., 1990. Association of Official Analytical Chemists, Official Methods of Analysis. $15^{\text {th }}$ Edition. Washington, DC

Brooks P.H., Beal J.D., Niven S.J., 2001. Liquid feeding of pigs: potential for reducing environmental impact and for improving productivity and food safety. Rec. Adv. Anim. Nutr. Aust. 13, 49-63

Bryhni E.A., Kjos N.P., Ofstad R., Hunt M., 2002. Polyunsaturated fat and fish oil in diets for growing-finishing pigs: effects on fatty acid composition and meat, fat, and sausage quality. Meat Sci. 62, 1-8

Canibe N., Jensen B.B., 2003. Fermented and nonfermented liquid feed to growing pigs: effect on aspects of gastrointestinal ecology and growth performance. J. Anim. Sci. 81, 2019-2031

Chinh B.V., Oanh B.T., Ha N.N., Viet T.Q., Khang D.T., Tinh N.T., 1995. Chemical Composition and Nutritive Value of Animal Feeds in Vietnam. Agricultural Publishing House, Ha Noi (Vietnam)

Department of Health, 1994. Nutritional Aspects of Cardiovascular Disease. Report on Health and Social Subject. London, No. 46

FAO, 2005. Statistical Data Base. Available online at http://faostat.fao.org

Folch J., Lees M., Sloane stanley G.H., 1957. A simple method for the isolation and purification of total lipids from animal tissues. J. Biol. Chem. 226, 497-509

Green S., Wiseman J., Cole D.J.A., 1988. Examination of stability, and its effect on the nutritive value, of fish silage in diets for growing pigs. Anim. Feed Sci.Tech. 21, 43-56

Hallenstvedt E., Kjos N.P., Rehnberg A.C., Øverland M., Thomassen M., 2010. Fish oil in feeds for entire male and female pigs: Changes in muscle fatty acid composition and stability of sensory quality. Meat Sci. 85, 182-190

Ho B.T., Paul D.R., 2009. Fatty acid profile of Tra Catfish (pangasius hypophthalmus) compared to Atlantic Salmon (Salmo solar) and Asian Seabass (Lates calcarifer). Int. Food. Res. J. 16, 501-506

Hong T.T.T., Lindberg J., 2007. Effect of cooking and fermentation of a pig diet on gut environment and digestibility in growing pigs. Livest. Sci. 109, 135-137

Hsia L.C., Lu G.H., 2004. The effect of high environmental temperature and nutrient density on pig performance, conformation and carcass characteristics under restricted feeding system. AsianAustr. J. Anim. Sci. 17, 250-258

Jensen B.B., Mikkelsen L.L., 1998. Feeding liquid diets to pigs. In: P.C Garnsworthy, J. Wiseman (Editors). Recent Advances in Animal Nutrition. Nottingham University Press (UK), pp. 107126

Jonsdottir R., Valdimarsdottir T., Baldursdottir B., Thorkelsson G., 2003. Influence of low fat fishmeal on fatty acid composition and sensory quality of pork. J. Muscle Foods 14, 51-65

Kim H.Y., Song Y.M., Jin S.K., Kim I.S., Kang Y.S., Lee S.D., Chowdappa R., Ha A.H., Kang S.M., 2006. The effect of change in meat quality parameters on pig Longissimus dorsi muscle by the addition of fermented persimmon shell diet. Asian-Austr. J. Anim. Sci. 19, 286-291 
Kjos N.P., Skrede A., Overland M., 1999. Effects of dietary fish silage and fish fat on growth performance and sensory quality of growing-finishing pigs. Can. J. Anim. Sci. 79, 139-147

Kouba M., 2006. Effects of dietary omega-3 fatty acids on meat quality of pigs and poultry. In: M.C. Teale (Editor). Omega 3 Fatty Acid Research. Nova Science Publishers, Inc. Chapter IV, pp. 225-239

Kristinsson H.G., Baldursdottir B., Jonsdottir R., Valdimarsdottir T., Thorkelsson G., 2001. Influence of feed fat source on fatty acid composition, unsaturation and lipid oxidation of backfat and sensory quality of pork. J. Muscle Foods 12, 285-300

Lallo C., Singh R., Donawa A., Madoo G., 1997. The ensiling of poultry offal with sugarcane molasses and Lactobacillus culture for feeding to growing/finishing pigs under tropical conditions. Anim. Feed Sci. Tech. 67, 213-222

Lam, P.T., Bui T.M., Nguyen T.T.T., Gooley G.J., Ingram B.A., Nguyen H.V., Nguyen P.T., De Silva S.S., 2009. Current status of farming practices of striped catfish, Pangasianodon hypophthalmus in the Mekong Delta, Vietnam. Aquaculture 296, 227-236

Lauridsen C., Andersen G., Andersson M., Danielsen V., Engberg R., Jakobsen K., 1999. Effect of dietary fish oil supplied to pigs from weaning to $60 \mathrm{~kg}$ liveweight on performance, tissue fatty acid composition and palatability of pork when slaughtered at $100 \mathrm{~kg}$ liveweight. J. Anim. Feed Sci. 8, 441-456

Michael J.A., 2001. Fat in swine nutrition. In: A.J. Lewis, L. Lee Southern (Editors). Swine Nutrition. $2^{\text {nd }}$ Edition. CRC Press. Washington, DC

Øverland M., Rørvik K.A., Skrede A., 1999. High-fat diets improve the performance of growingfinishing pigs. Acta Agr. Scand. 49, 83-88

Samuels W., Fontenot J., Allen V., Flick G., 1992. Fermentation characteristics of ensiled seafood wastes and low-quality roughages. Anim. Feed Sci.Tech. 38, 305-317

Scholten R.H.J., van der Peet-Schwering C.M.C., Verstegen M.W.A., den Hartog L.A., Schrama J.W., Vesseur P.C., 1999. Fermented co-products and fermented compound diets for pigs: a review. Anim. Feed Sci.Tech. 82, 1-19

Stahly T.S., 1984. Use of fats in diets for growing pigs. In: J. Wiseman (Editor). Fats in Animal Nutrition. Butterworths. London, pp. 313-331

Stahly T.S., Cromwell G., 1979. Effect of environmental temperature and dietary fat supplementation on the performance and carcass characteristics of growing and finishing swine. J. Anim. Sci. 49, 1478-1488

Teye G.A., Sheard P.R., Whittington F.M., Nute G.R., Stewart A., Wood J.D., 2006. Influence of dietary oils and protein level on pork quality. 1. Effects on muscle fatty acid composition, carcass, meat and eating quality. Meat Sci. 73, 157-165

Thuy N.T., Lindberg J.E., Ogle B., 2010. Effect of additive on the chemical composition of tra catfish (Pangasius hypophthalmus) by-product silages and their nutritive value for pigs. AsianAustr. J. Anim. Sci. 23, 762-771

Urlings H.A., Mul A.J., Van’t Klooster A.T., Bijker P.G., van Logtestijn J.G., Van Gils L.G., 1993. Microbial and nutritional aspects of feeding fermented feed (poultry by-products) to pigs. Vet. Quartely 15, 146-151

Van Winsen R.L., Urlings B.A.P., Lipman L.J.A., Snijders J., Keuzenkamp D., Verheijden J.H.M.,Van Knapen F., 2001. Effect of fermented feed on the microbial population of the gastrointestinal tracts of pigs. Appl. Environ. Microbiol. 67, 3071-3076

Vidotti R., Viegas E., Carneiro D., 2003. Amino acid composition of processed fish silage using different raw materials. Anim. Feed Sci.Tech. 105, 199-204

Zahar M., Benkerroum N., Guerouali A., Baou S., Alahiane L., 2002. Biological ensiling of sardine wastes in sugarcane molasses for their valorization in animal feeding: Microbiological study. In: Proceedings of International Symposium on Environmental Pollution Control and Waste Management, Tunis (EPCOWM'2002), pp. 304-311 